\title{
Geophysical study and structural modelling of a mass movement in upper Austria
}

\author{
M. G. Schreilechner, C. G. Eichkitz \& J. Amtmann \\ Joanneum Research, Geophysics and Geothermics, Austria
}

\begin{abstract}
In this paper, a typical workflow for the generation of a three dimensional structural model of a mass movement is presented. For the demonstration of this workflow, the mass movement of the Gschliefgraben (Upper Austria) is used as a case study. The Gschliefgraben is situated on the eastern shore of Lake Traunsee, Upper Austria, on the transition of the Northern Calcareous Alps and the Flysch Zone. This mass movement shows various phases of activity since the last glacial period (Würm), with the last huge landslide in November 2007. This landslide is built up as an earthflow system with occasional mudflows and can be cross-bedded with debris flows and torrential sediments. Due to the continuous accumulation of unconsolidated sediments, subaqueous earth slides in the area of the Gschliefgraben can be observed. Multiple seismic reflection and refraction profiles were measured before and after the last huge landslide. In addition, there are numerous wells and several digital elevation models were recorded too. The seismic reflection profiles were interpreted using a seismic stratigraphic approach. These interpretations in combination with information from the refraction profiles, the wells and the digital elevation models were used to generate a high resolution three-dimensional structural model. The focus of this modelling process was on the western part of the mass movement (base of the mass movement). With the help of the interpretation and the three dimensional model, three phases of mass movements prior to the most recent one can be distinguished.

Keywords: mass movement, debris flow, geophysics, seismic reflection, seismic refraction, upper Austria.
\end{abstract}




\section{Introduction}

Geophysical methods are useful tools for detailed description of sub surfaces of mass movements. Often multiple geophysical methods are applied to characterize the structure, location of the sliding plane, or the interior composition (Mauritsch et al. [1], Arndt et al. [2], Bichler et al. [3], Bell et al. [4] Schrott and Sass [5], Millahn et al. [6], Niesner and Weidinger [7]). For the description of the internal structure of mass movements the most accurate method is seismic reflection. In the case of mass movement description usually 2D seismic reflection profiles are used (e.g. Brückl et al. [8], Brückl and Brückl [9], Stucchi et al. [10], Stucchi and Mazotti [11]). A more accurate description can be achieved by $3 \mathrm{D}$ seismic, but due to the high costs for acquisition $3 \mathrm{D}$ seismic is at the moment not affordable for mass movement studies.

In the course the Gschliefgraben project, which lasted around five years, four seismic reflection profiles and 20 seismic refraction profiles were acquired. The aim of this project was to get a detailed description of the interior of the most recent landslide and to gain knowledge about older landslides and their triggers.

\section{Geological overview}

The Gschliefgraben is located at the eastern shore of Lake Traunsee and north of mountain Traunstein $(1619 \mathrm{~m})$, Upper Austria. The area lies on the border of the Northern Calcareous Alps and the Flysch Zone (Egger [12]) and is related to the highly deformed tectonic window of the Ultrahelvetic (Prey [13, 14]) (fig. 1).

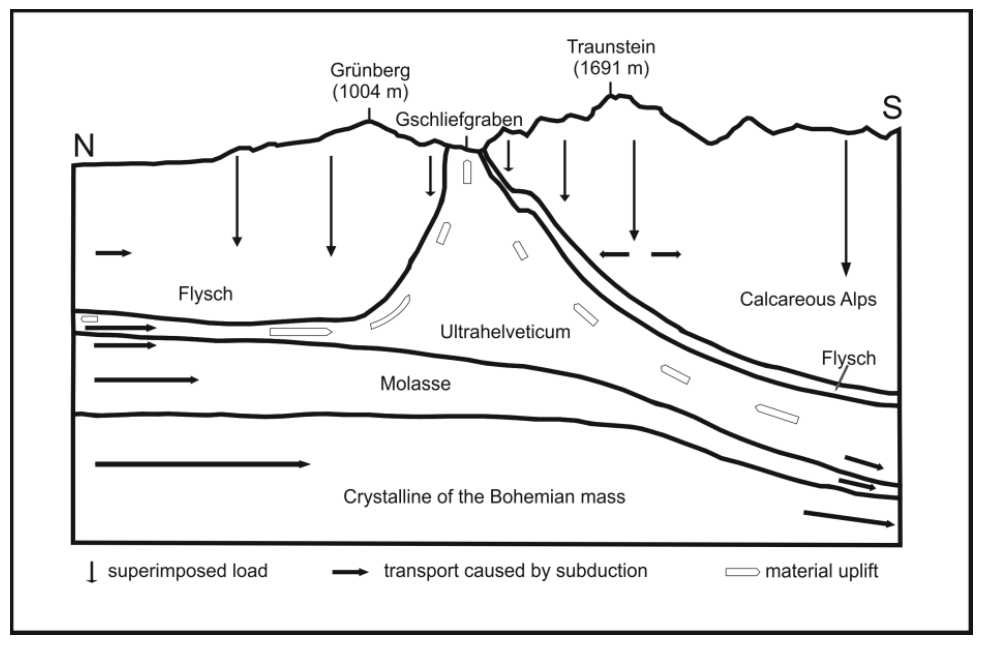

Figure 1: Schematic north-south cross-section showing the principle geology of the Gschliefgraben area and its surroundings (modified after Daurer and Schäffer [15]). 
After the high glacial stage of the Würm the mass movement system of the Gschliefgraben area evolved as the glacier of Lake Traunsee melted (Van Husen [16]). Since then multiple phases of mass movements occurred. A compilation of historical landslides in the Gschliefgraben is given by Weidinger [17]. As a consequence to the continuous accumulation of unconsolidated sediments, subaqueous earthslides occurred (Egger [12]).

The most recent landslide (fig. 2) occurred in November 2007. This earth flow was presumably triggered by a rock fall in April 2006 (Marschallinger et al. [18]).

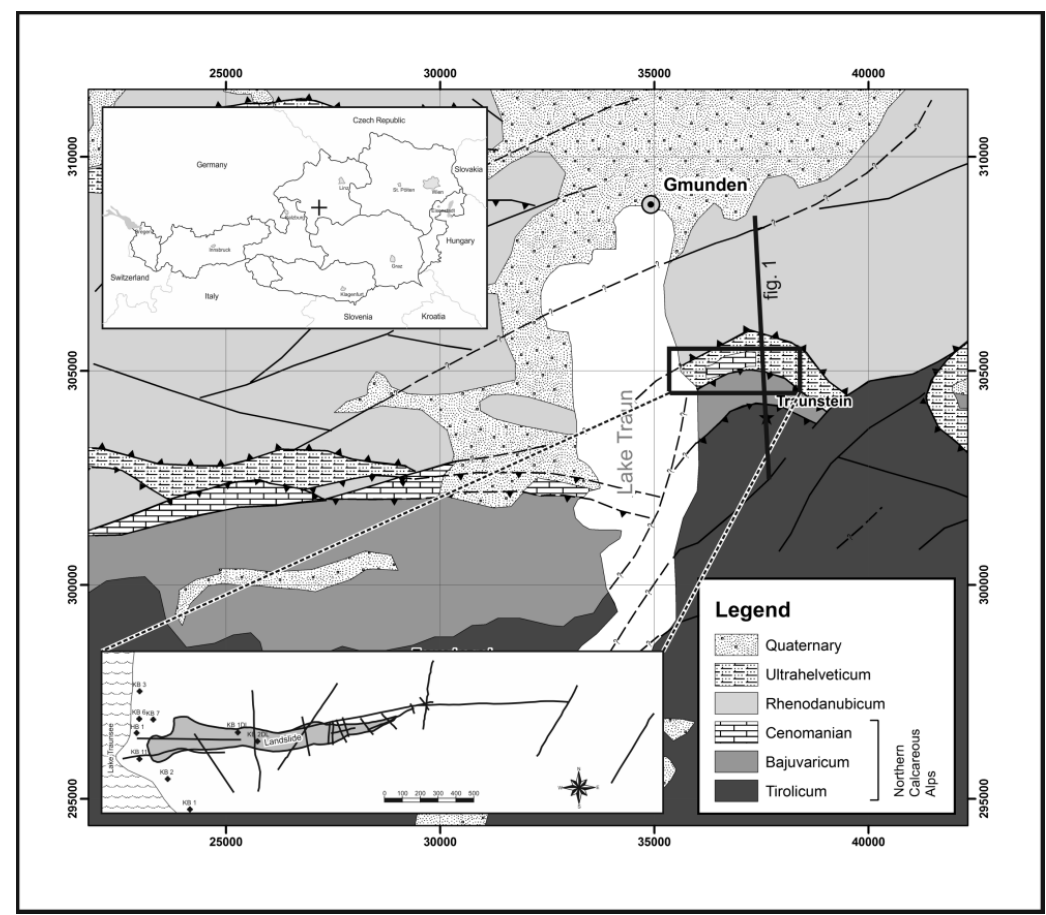

Figure 2: The project site is located on the eastern shore of Lake Traunsee, Upper Austria (box). In the background a geological map of Upper Austria (modified after Egger [19]; Egger and Van Husen [20]) is shown. In the lower left picture the outline of the most recent landslide, the available wells, and the position of the seismic reflection and refraction profiles are shown. 


\section{Data}

In the Gschliefgraben area multiple geophysical methods were used for monitoring landslide activity (e.g. Niesner and Weidinger [7], Supper et al. [21]). In the course of a project, funded by the Austrian Academy of Sciences and by the UN International Strategy of Disaster Reduction, several reflection and refraction profiles were recorded prior to the most recent large landslide. Details on the acquisition and processing of the seismic reflection and refraction profiles can be found in Eichkitz et al. [22] and Marschallinger et al. [18]. After the landslide occurred additional refraction profiles were collected. These had the intention to reveal a clearer image of the landslide interior. Additionally, several digital elevation models were recorded prior and after the most recent landslide (fig. 3). With the help of these digital elevation models it was possible to give a first estimation of the volume of the recent landslide.

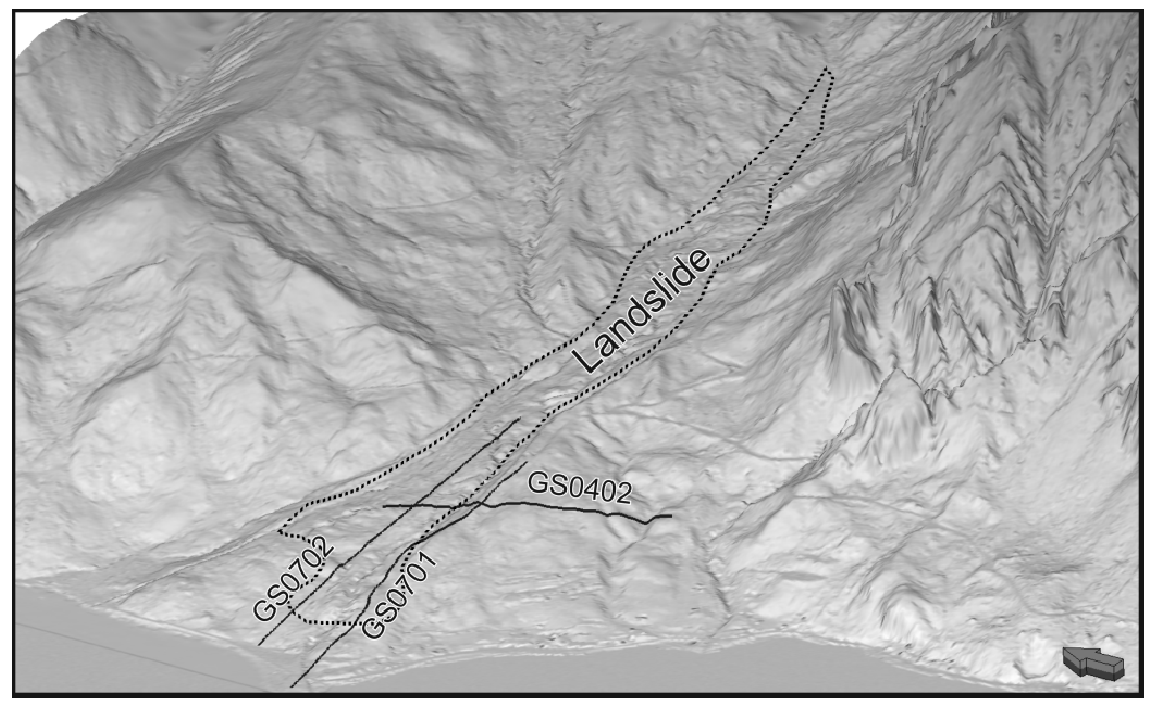

Figure 3: Three dimensional representation of the Gschliefgraben area. The black dotted line indicates the outline of the most recent landslide. The black lines indicate the position of the seismic reflection lines.

The seismic reflection profiles were recorded using $3 \mathrm{~m}$ receiver spacing. The refraction profiles measured prior to the landslide had $10 \mathrm{~m}$ receiver spacing, whereas the refraction profiles after the landslide were measured with $2 \mathrm{~m}$ receiver spacing.

In addition to the seismic data several wells and well $\log$ information (Gamma Ray, Density, Resistivity, and Temperature) and high resolution digital elevation models (measured prior and after the landslide) were available. In wells HB1, KB1 and KB2 (see figure 2) wooden particles were found that could be dated using the ${ }^{14} \mathrm{C}$ method (Eichkitz et al. [22]). 


\section{Interpretation}

Seismic interpretation is usually done in the time domain and afterwards converted to depth using velocity information from wells. Due to the small number of wells and the lack of a checkshot survey we used stacking velocities for the depth conversion of the seismic sections. Principally, well tops and seismic reflectors can be correlated by calculation of synthetic seismograms. In the case of the wells in the study area it was not possible to measure sonic logs. Therefore, it was not possible to directly identify reflectors using a synthetic seismogram. As a consequence we decided to base our interpretation on the identification of prominent changes in seismic facies (reflection configuration, amplitude, frequency, and continuity of reflectors) and by using a sequence stratigraphical approach (Posamentier and Allen [23], Cantuneanu [24], Coe [25]). By applying this method, five different seismic facies packages were identified (see fig. 4).

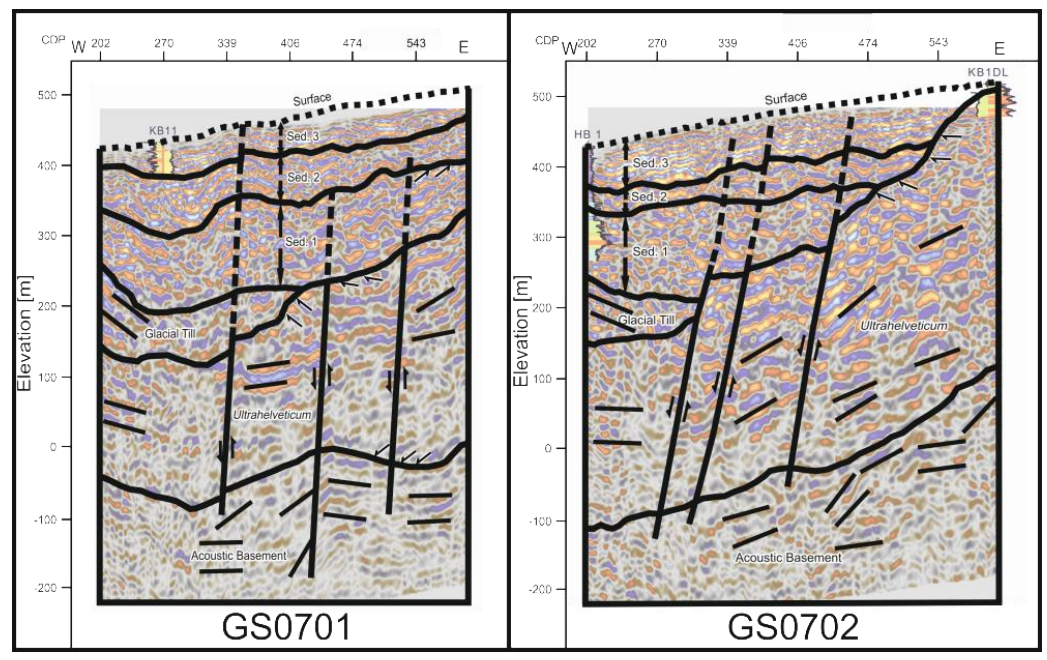

Figure 4: Interpreted seismic reflection profiles GS0701 and GS0702. Both seismic profiles are W-E striking. Interpretation of the profiles was done by the concept of seismic sequence stratigraphy. The small arrows indicate downlaps and toplaps.

The lowermost zone could not be associated with any geological formation, because no well penetrates this stratum. Therefore, this zone is described as seismic acoustic basement. In this zone rapid changes of dip of reflectors can be observed. In some parts of this zone (especially in the western parts of the sections) chaotic pattern with low continuity can be observed. In the eastern parts of the seismic sections reflectors dipping between $0^{\circ}$ and $60^{\circ}$ can be seen. 
In contrast to the chaotic pattern of the acoustic basement, the overlying zone shows continuous reflectors with rather constant dipping to the west. This zone is interpreted to be Ultrahelvetic rocks, which is confirmed by well KB1DL. The lowest part of this zone is partly characterized by downlapping reflectors. The top of this zone is characterized by toplaps. This leads to the interpretation that the top of the Ultrahelvetic rocks is an erosional surface.

In the western part of GS0701 and GS0702, above the Ultrahelvetic rocks, a change in dip of reflectors can be observed. The Ultrahelvetic rocks are dipping west, whereas the zone above is dipping east. In this area low amplitude and low frequency reflections are visible. Unfortunately, no well penetrates this zone. It could be interpreted as either earthflow toe deposits or as glacial till. Due to the east dipping this zone we interpreted it as glacial till. As the Gschliefgraben evolved when the Traun glacier melted (Van Husen [16]), this zone might be the remaining glacial till from this glacier. Comparison to other studies on seismic facies interpretation from the Upper Inn Valley supports this idea. Gruber and Weber [26] interpreted six seismic profiles from the Upper Inn Valley. In their work they describe the appearance of glacial till in the seismic as short, low frequency, and uneven reflectors. Similar features can be observed in the Gschliefgraben seismic sections.

Above the Ultrahelvetic rocks and the glacial tills are several layers of unconsolidated rocks. With the help of the seismic reflection profiles it is possible to interpret zones of similar seismic facies. Each seismic facies is characterized by amplitude, frequency, and continuity of reflectors. Based on these categories three different phases of sedimentation can be distinguished.

The lowermost phase of sedimentation (Sed. 1) is characterized by low frequency reflectors with chaotic reflection pattern. The top of this phase is characterized by toplapping reflectors, which is again an indication for an erosional surface. This phase of sedimentation is penetrated by well HB1 and wooden samples were found at the upper part of this zone. These samples were dated to be $11,275 \pm 375$ years old. According to interpretation of the Gamma Ray log measured in HB1 at least four phases of earth- and mudflows and four phases of torrential sediments occurred (fig. 5). As HB1 did not drill completely through this zone the total number of phases of mud- and earthflows cannot be determined.

The middle phase of sedimentation (Sed. 2) is characterized by higher frequencies than the lowermost phase. The reflectors are mostly parallel with minor occurrence of discontinuities. This phase shows less dip than the lowermost phase. Regarding the Gamma Ray log from HB1 the upper part is solely build-up of torrential sediments. The lower part shows higher shale content, but in comparison to the lowermost phase no well-defined mud- or earthflows occurred. In this zone only one small vertical section is interpreted as mud- or earthflow at a depth of approximately $82 \mathrm{~m} \mathrm{MD.}$

The topmost phase (Sed. 3) is characterized by high amplitude and high frequency reflectors. In most parts the reflectors are parallel and show good continuity. This zone is penetrated by wells HB1, KB11, and KB1DL. The Gamma Ray logs of these wells show completely different results. The Gamma 


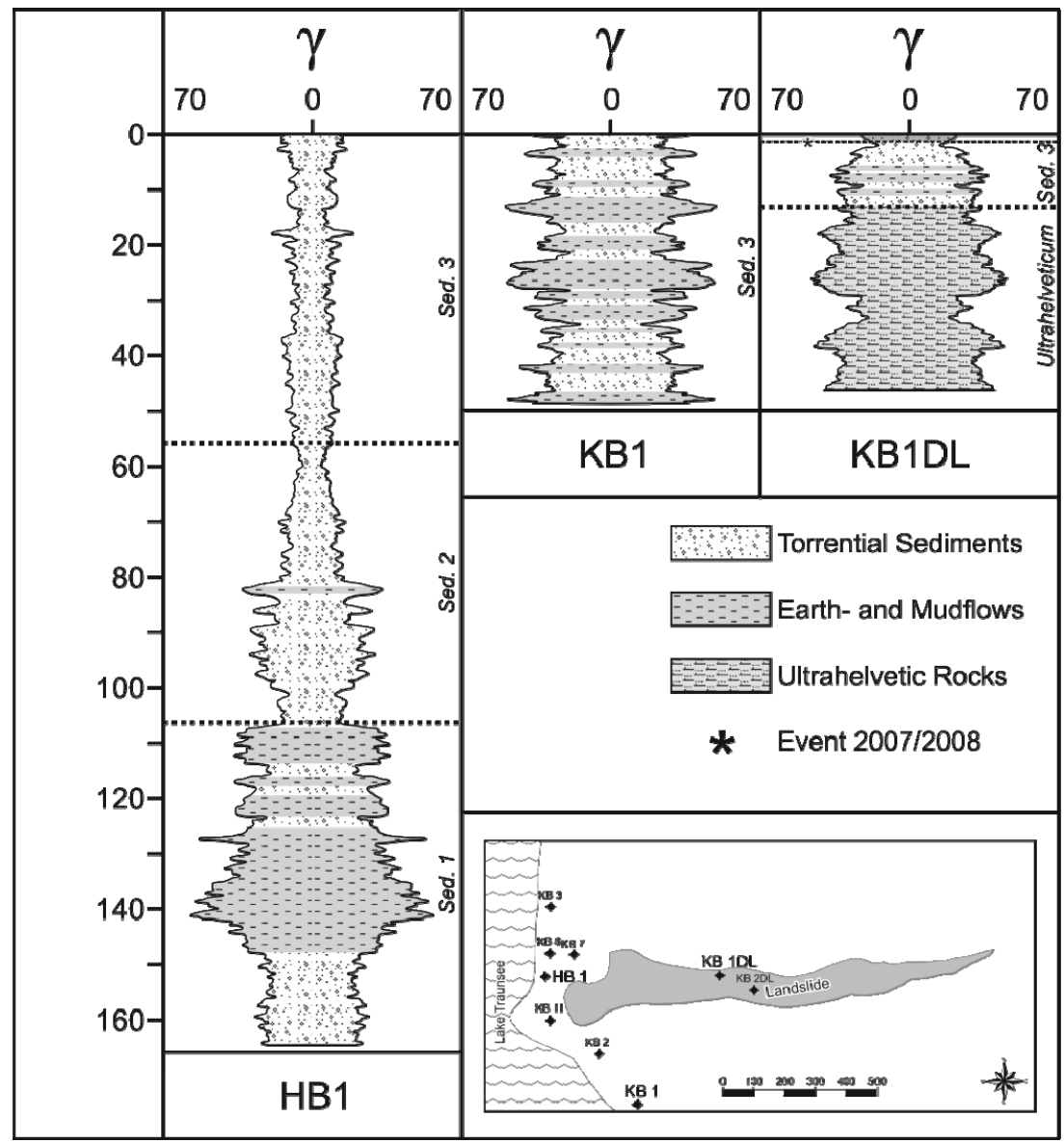

Figure 5: Gamma Ray logs for wells HB1, KB1, and KB1DL. The logs indicate zones with higher shale content, which are interpreted as earth- and mudflows. The zones with lower Gamma Ray values indicate sandy zones, which are interpreted as torrential sediments. Well HB1 was drilled prior to the most recent landslide, whereas the wells KB1 and KB1DL where drilled after the last landslide.

Ray from $\mathrm{HB} 1$ has low values and is therefore interpreted as torrential sediments. The Gamma Ray from well KB11 shows multiple phases of change between earthflows and torrential sediments. The vertical range of these phases is between $1 \mathrm{~m}$ and $5 \mathrm{~m}$. Well KB1DL shows three phases of mudflows. In this well Ultrahelvetic rocks are reached after $15 \mathrm{~m}$.

On the seismic sections it is not possible to distinguish between the torrential sediments and mud- and earthflows. The seismic indicates three phases of different seismic facies, with different seismic characteristics. Only with the help of the well $\operatorname{logs}$ it is possible to see further alternation between torrential sediments and mud- and earthflows. 
Additionally to the sequence stratigraphic interpretation a structural interpretation of the reflection profiles was performed. For the lower zones (seismic acoustic basement and Ultrahelvetic rocks) it was possible to identify three normal faults that are indicated by discontinuities in seismic reflectors. Above these geological zones it was not possible to identify discontinuities in the reflectors that correspond to these faults. However, flexures in seismic reflectors might indicate that the faults were still active at the time when the unconsolidated sediments (Sed.1 to Sed. 3) were deposited. This interpretation is supported by the work of Daurer and Schäffer [15], who postulated that in the area of the Gschliefgraben neotectonic events with intensified seismicity occur. These neotectonic events are related to the Traunsee fault system (Geyer [27]).

Based on the interpretation results of the seismic reflection profiles a structural model was built. The input were the interpreted faults, the top of the Ultrahelvetic rocks, the top of the glacial till, and the tops of the three phases of unconsolidated sediments. A detailed description on the modelling process can be found in Amtmann et al. [28].

The final structural model (fig. 6) has a total volume of $56 \times 10^{6} \mathrm{~m}^{3}$. With the help of this structural model it is possible to determine the volumetric of each zone and to generate structural maps.

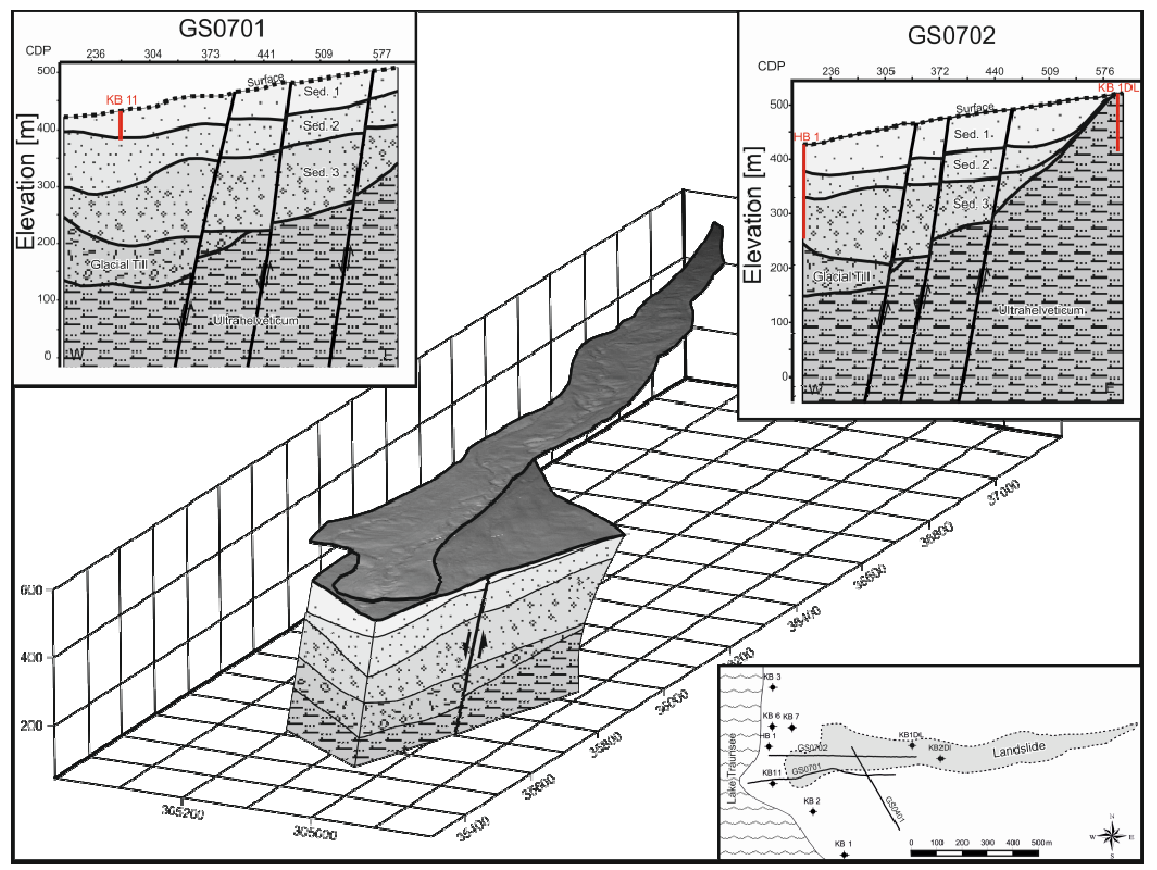

Figure 6: Final structural model derived from seismic reflection profiles. The three dimensional model consists of five layers. On the right two cross-sections are shown (modified after Eichkitz et al. [22]). 
The refraction profiles were taken as input for two different modelling approaches. The first modelling approach uses the refraction profiles (refraction tomography) directly. On the profiles velocity boundaries are picked. These velocity boundaries are then used to generate surfaces of constant velocities (fig. 7). A detailed description on this method can be found in Marschallinger et al. [18]. The second approach uses geostatistics (Amtmann and Eichkitz [29]). The results from processing of the refraction seismic are geostatistically distributed to generate a three-dimensional property model. Based on these two models it is possible to define the bottom of the most recent landslide and to identify further surfaces within the topmost zone of the reflection seismic model.

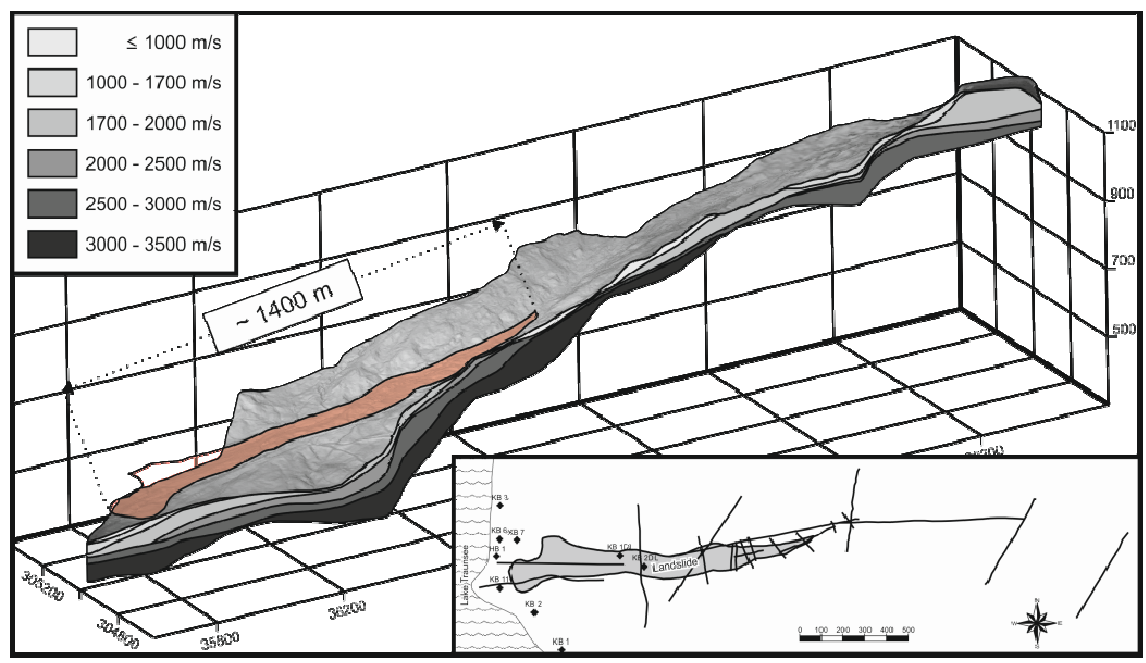

Figure 7: Final structural model based on the seismic refraction profiles. In the model six layers are included, where each of these layers represent a specific velocity range.

\section{Conclusion}

Seismic reflection data can indicate zones of different seismic facies. Based on these geophysical data it was possible to identify three phases of landslides that occurred prior to the most recent landslide. From the seismic data it was not possible to distinguish between torrential sediments and mud- or earthflows, but, by integrating well logs from nearby wells it was possible to identify several alterations of torrential sediments and mud- or earthflows. Modelling of seismic refraction data led to identification of the bottom surface of the most recent landslide and to identification of further surfaces within the topmost zone of the reflection seismic model. 


\section{Acknowledgements}

The initial project was funded by the Austrian Academy of Sciences (Geophysik der Erdkruste) and by the UN International Strategy of Disaster Reduction (UN/ISDR). The geophysical field studies were partly funded by Joanneum Research. We would like to thank the Department of Applied Geophyiscs, University of Leoben, and especially Prof. Weber who initiated this research project. We thank Hydroisotop $\mathrm{GmbH}$ for providing the ${ }^{14} \mathrm{C}$ dating of the wood samples. In the course of the last phase of mass movement (November 2007) additional geophysical surveys were commissioned by the Austrian Service for Torrent and Avalanche Control. For linguistic improvements of this paper and constructive discussion we thank Neil Bird (Joanneum Research, Energy Research).

\section{References}

[1] Mauritsch, H.J., Seiberl, W., Arndt, R., Römer, A., Schneiderbauer, K. and Sendlhofer, G.P., Geophysical investigations of large landslides in the Carnic Region of southern Austria. Engineering Geology, 56, pp. 373388, 2000.

[2] Arndt, R., Römer, A., Sendlhofer, G. and Restner, U., Geophysical reconnaissance methods for landslides in softrocks. Interpraevent 2000, pp. 191-201, 2000.

[3] Bichler, A., Bobrowsky, P., Best, M., Douma, M., Hunter, J., Calvert, T. and Burns, R., Three-dimensional mapping of a landslide using a multigeophysical approach: The Quesnel Forks landslide. Journal of the International Consortium of Landslides, 1, pp. 29-40, 2004.

[4] Bell, R., Kruse, J.E., Garcia, A., Glade, T. and Hördt, A., Subsurface investigations of landslide using geophysical methods - geoelectrical applications in the Swabian Alb (Germany). Geographica Helvetica, 61, pp. 201-208, 2006.

[5] Schrott, L. and Sass, O., Application of field geophysics in geomorphology: Advances and limitations exemplified by case studies. Geomorphology, 93, pp. 55-73, 2008.

[6] Millahn, K., Weber, F., Niesner, E., Grassl, H., Hyden, W., Kerschner, F., Morawetz, R., Schmid, C. and Weidinger, J.T., Ergebnisse geophysikalischer Untersuchungen im Gschliefgraben bei Gmunden (Oberösterreich) im Hinblick auf Massenbewegungen. Jahrbuch der Geologischen Bundesanstalt, 148, pp. 117-132, 2008.

[7] Niesner, E. and Weidinger, J.T., Investigation of a historic and recent landslide area in Ultrahelvetic sediments at the northern boundary of the Alps (Austria) by ERT measurements. The Leading Edge, 27, pp. 260269, 2008.

[8] Brückl, E., Brückl, J. and Heuberger, H., Present structure and prefailure topography of the giant rockslide of Köfels. Zeitschrift für Gletscherkunde und Glazialgeologie, 37, pp. 49-79, 2001. 
[9] Brückl, E. and Brückl, J., Geophysical models of the Lesachriegel and Gradenbach deep-seated mass-movements (Schober range, Austria). Engineering Geology, 83, pp. 254-272, 2006.

[10] Stucchi, E., Zgur, F. and Baradello, L., Seismic land-marine acquisition survey on the Great Ancona Landslide. Near Surface Geophysics, 4(3), pp. 235-243, 2005.

[11] Stucchi, E. and Mazotti, A., 2D seismic exploration of the Ancona landslide (Adriatic Coast, Italy). Geophysics, 74, pp. 139-151, 2009.

[12] Egger, H., Erläuterungen zu Blatt 66 Gmunden. Geologische Bundesanstalt: Wien, 2007.

[13] Prey, S., Der Gschliefgraben in der Flyschzone bei Gmunden. Mitteilungen der Geologischen Gesellschaft, 44, pp. 263-266, 1951.

[14] Prey, S., Das Ultrahelvetikum-Fenster des Gschliefgrabens südöstlich von Gmunden (Oberösterreich). Jahrbuch der Geologischen Bundesanstalt, 126, pp. 95-127, 1983.

[15] Daurer, A. and Schäffer, G., Arbeitstagung der Geologischen Bundesanstalt 1983. Geologische Bundesanstalt: Wien, pp. 1-65, 1983

[16] Van Husen, D., Zur Fazies und Stratigraphie der jungpleistozänen Ablagerungen im Trauntal. Jahrbuch der Geologischen Bundesanstalt, 120, pp. 1-130, 1977

[17] Weidinger, J.T., Das Gschliefgraben-Rutschgebiet am Traunsee-Ostufer (Gmunden/OÖ) - Ein Jahrtausende altes Spannungsfeld zwischen Mensch und Natur. Jahrbuch der Geologischen Bundesanstalt, 149, pp. 195-206, 2009.

[18] Marschallinger, R., Eichkitz, C.G., Gruber, H., Heibl, K., Hofmann, R. and Schmid, K., The Gschliefgraben landslide (Austria): A remediation approach involving torrent and avalanche control, geology, geophysics, geotechnics and geoinformatics. Austrian Journal of Earth Sciences, 102(2), pp. 35-51, 2009.

[19] Egger, J., Geologische Karte der Republik Österreich 1:50.000, Blatt 66 Gmunden, Geologische Bundesanstalt: Wien, 1996.

[20] Egger, H. and Van Husen, D., Geologische Karte der Republik Österreich 1:50.000, Blatt 67 Grünau im Almtal. Geologische Bundesanstalt: Wien, 2007.

[21] Supper, R., Baron, I., Ita, A., Winkler, E., Jochum, B. and Motchka, K., Airborne geophysical survey and innovative landslide monitoring at Gschliefgraben, Austria. Near Surface $2010-16^{\text {th }}$ European Meeting of Environmental and Engineering Geophysics, B09, 2010.

[22] Eichkitz, C.G., Schreilechner, M.G., Amtmann, J. and Schmid, C., Shallow seismic reflection study of the Gschliefgraben landslide deposition area - Interpretation and three dimensional modeling. Austrian Journal of Earth Sciences, 102(2), pp. 52-60, 2009.

[23] Posamentier, H.W. and Allen, G.P., Siliciclastic sequence stratigraphy: concepts and applications, SEPM Concepts in Sedimentology and Paleontology: Tulsa, pp. 1-210, 1999. 
48 Monitoring, Simulation, Prevention and Remediation of Dense and Debris Flows IV

[24] Cantuneanu, O., Principles of Sequence Stratigraphy, Elsevier, Amsterdam, 2006

[25] Coe, A., The Sedimentary Record of Sea-Level Change, Cambridge University Press, Cambridge, 2003

[26] Gruber, W. and Weber, F., Ein Beitrag zur Kenntnis des glazial übertieften Inntals westlich von Innsbruck. Sitzungsbericht der Österreichischen Akademie der Wissenschaften, 210, pp. 3-30, 2003.

[27] Geyer, G., Über die Querverschiebung am Traunsee. Verhandlungen der K.K. geologischen Reichsanstalt, 4, pp. 67-102, 1917.

[28] Amtmann, J., Eichkitz, C.G., Schreilechner, M.G., Grassl, H. and Schmid, C., Dreidimensionale Modellierung von Massenbewegungen aus geophysikalischen Daten (Gschliefgraben, Österreich). Online Datenerfassung, berührungslose Messverfahren, 3D-Modellierung und geotechnische Analyse in Geologie und Geotechnik; Computerorientierte Geologie Salzburg 2009, eds. R. Marschallinger, W. Wanker and F. Zobl, Wichmann Verlag: Berlin, pp. 82-96, 2009.

[29] Amtmann, J. and Eichkitz, C.G., Erzeugung eines dreidimensionalen Geschwindigkeitsmodells auf Basis von Refraktionstomographieauswertungen im Gschliefgraben, Österreich. Journal of Alpine Geology, 52, pp. 81, 2010. 